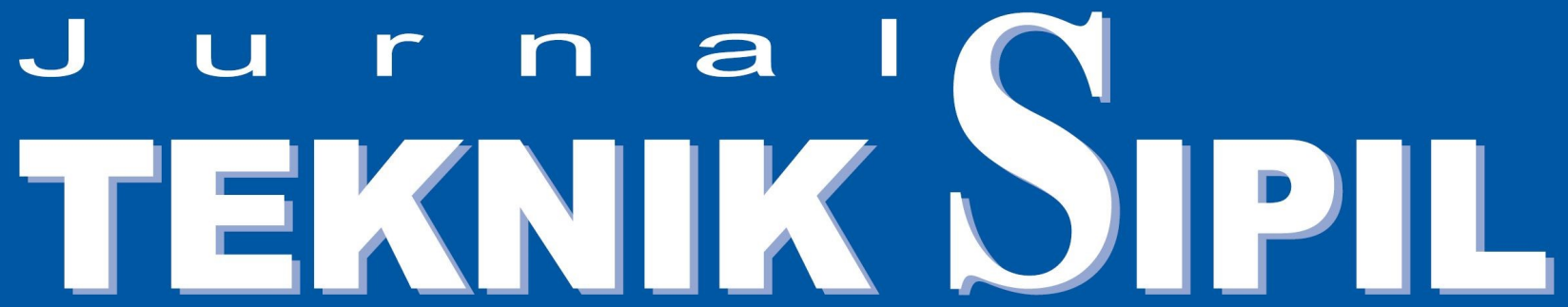

Yanuar Haryanto, Iman Satyarno, Djoko Sulistyo

Abadi Dwi Saputra, Sigit Priyanto, Imam Muthohar, Magda Bhinnety

JF. Soandrijanie Linggo, Julius Yoga Kurniawan

Raden Aji Laksono, Imam Basuki, Y. Lulie

Alfian, Haji Gussyafri

Randy Kristovandy Tanesia, Dwi Suryani, Frederick Martce Yudha, Juniastuti Ramba

Sasmito, Bambang Triatmodjo, Joko Sujono, Sri Harto, Br.

Novdin M Sianturi
Analisis Daya Dukung Beban Balok Beton Bertulang Tampang T Dengan Perkuatan Wire Rope Pada Daerah Momen Negatif Menggunakan Program Response-2000 dan Metode Pias

Pengkajian Tingkat Beban Kerja Mental Pilot Pesawat Terbang Dalam Melaksanakan Tahap Fase Terbang (Phase Of Flight)

Penggunaan PVC Sebagai Bahan Tambah Pada Beton Aspal

Analisis Biaya Operasional Kendaraan (BOK) dan Tingkat Okupansi Angkutan Taksi

Daerah Istimewa Yogyakarta

Penilaian Penawaran Terendah Yang Responsif Pada Pengadaan Barang dan Jasa Pemerintah Berbasis Teknologi Komputasi

Kajian Segmentasi Pasar dan Strategi Pemasaran Usaha Jasa Konstruksi di Negara-negara Asean (Studi Kasus: Indonesia vs Filipina)

Pengaruh Kondisi Awal Kelengasan Tanah Terhadap Debit Puncak Hidrograf Satuan

Evaluasi Terhadap Pengelolaan Sampah Dalam Meningkatkan Pelayanan Aset di Kota Pematangsiantar

\begin{tabular}{|l|l|l|c|c|c|}
\hline J. Tek. Sip. & Vol. 13 & No. 3 & $\begin{array}{c}\text { HIm. } \\
173-254\end{array}$ & $\begin{array}{c}\text { Yogyakarta } \\
\text { Oktober 2015 }\end{array}$ & $\begin{array}{c}\text { ISSN } \\
1411-660 X\end{array}$ \\
\hline
\end{tabular}




\title{
ANALISIS BIAYA OPERASIONAL KENDARAAN (BOK) DAN TINGKAT OKUPANSI ANGKUTAN TAKSI DAERAH ISTIMEWA YOGYAKARTA
}

\author{
Raden Aji Laksono, Imam Basuki, Y. Lulie. \\ Program Pascasarjana, Magister Teknik Sipil, Universitas Atma Jaya Yogyakarta \\ Jh Babarsari No. 43 Yogyakarta \\ e-mail : imbas2004@gmail.com,yolulie@yahoo.co.id, raden_ajilaksono@yahoo.com.
}

\begin{abstract}
Taxi's purpose is to safety economic, comfort, swift, bring, but it is need a important factor. Such as condition of the taxi, especially their services which its important factors that user wants. One of the service task is cost, then it need controlling and accounting objective operational cost and accurate then it can use to take some dec ision.

The purpose of this research is to analyze occupancy of the taxi's user and yearly vehic le operating cost (VOC) for taxi. The method of the research is with in direct observation on taxi's company and interview the owner. The vehicle operating cost (VOC) calculation using basic cost from Direc torate General Of Land Transportation 2002.

The result of this research is with data's from seven taxi companys, taxi's occupancy is 33\%. According Directorate General Of Land Transportation SK.1905/KP.801/DRJD/2010 that taxi's occupancy in DIY is less than enough, of then it services in the city need improvements. One of way to improve is using some application on such as G-maps, Ruby on Rails that combine with Android software. Average net income from seven taxi's company by calculation is \pm 80.000 .000 ,it's mean that taxi's sector is affordable to do.
\end{abstract}

Keywords: Taxi transport, level of service, the level of occup ancy, vehicle operating cost (VOC)

\section{PENDAHULUAN}

Seiring dengan makin pesatnya jumlah penduduk, kebutuhan sarana dan prasarana transportasi sangat dibutuhkan untuk mengimbangi berbagai aktifitas dari penduduk. Angkutan umum merupakan sarana yang dibutuhkan untuk menunjang kelancaran mobilitas yang tinggi dan juga menunjang pergerakan seseorang dari suatu tempat ke tempat lain. Salah satu angkutan umum yang tersedia di kota Yogyakarta adalah angkutan taksi.

Tujuan pencapaian keinginan angkutan taksi adalah yang aman, nyaman, ekonomis dan lancar, perlu memperhatikan kondisi dari angkutan taksi yang beroperasi tersebut, terutama pelayanannya yang dianggap sangat penting terhadap pemakai jasa angkutan taksi. Salah satu ukuran tingkat pelayanan adalah biaya, sehingga diperlukan pengontrolan dan perhitungan biaya yang objektif dan cermat agar dapat dipergunakan sebagai dasar pengambil keputusan

\section{TINJAUAN PUSTAKA}

\section{Angkutan Taksi}

Peraturan Pemerintah Nomor 74 Tahun 2014 pasal 42 tentang Angkutan Jalan bahwa pelayanan orang dengan angkutan taksi merupakan pelayanan dari pintu ke pintu dengan wilayah operasi dalam wilayah perkotaan. Sistem pembayaran pada angkutan taksi dilakukan berdasarkan argometer yang dilengkapi dengan alat pencetak bukti pembayaran. Berikut merupakan kendaraan yang dipergunakan untuk pelayanan angkutan orang dengan menggunakan taksi.

a. Mobil penumpang sedan yang memiliki tiga ruang.

b. Mobil penumpang bukan sedan yang memiliki dua ruang.

\section{Okupansi}

Okupansi merupakan perbandingan prosentase antara panjang perjalanan taksi isi penumpang dengan total panjang taksi berpenumpang maupun taksi kosong (Tamin, 1997) 
Tabel 1 Okupansi Harian Rata-rata

\begin{tabular}{|c|c|c|c|c|c|c|}
\hline No & $\begin{array}{l}\text { Nama } \\
\text { Taksi }\end{array}$ & $\begin{array}{c}\text { Panjang } \\
\text { Perjalanan } \\
\text { per hari } \\
(\mathbf{k m})\end{array}$ & $\begin{array}{c}\text { Jarak } \\
\text { Tempuh/Trip/hari } \\
\text { (km) }\end{array}$ & $\begin{array}{c}\text { Jml. Trip } \\
\text { per hari } \\
\text { (kali) }\end{array}$ & $\begin{array}{c}\text { Jarak } \\
\text { Perjalanan } \\
\text { Isi per hari } \\
\quad(\mathbf{k m}) \\
\end{array}$ & Okupansi (\%) \\
\hline $\mathbf{a}$ & b & C & D & $\mathbf{e}$ & $f=d x e$ & $g=f / c \times 100 \%$ \\
\hline 1 & ATLAS & 243,80 & 8,02 & 14,30 & 114,69 & $47 \%$ \\
\hline 2 & CENTRIS & 248,20 & 7,60 & 18,62 & 141,51 & $57 \%$ \\
\hline 3 & KOSTI & 240,00 & 6,84 & 20,36 & 139,26 & $58 \%$ \\
\hline 4 & PANDU & 239,40 & 7,59 & 16,40 & 124,48 & $52 \%$ \\
\hline 5 & $\begin{array}{l}\text { PURI } \\
\text { KENC. }\end{array}$ & 241,60 & 6,73 & 19,33 & 130,48 & $54 \%$ \\
\hline \multicolumn{2}{|c|}{ Rata-rata } & 242,60 & 7,36 & 17,80 & 130,08 & $53,6 \%$ \\
\hline
\end{tabular}

Sumber : Sriwidodo (2005)

Tabel 2 Besar Biaya Operasional Taksi Per Km

\begin{tabular}{|c|c|c|c|c|c|c|}
\hline No & $\begin{array}{l}\text { Nama } \\
\text { Taksi }\end{array}$ & $\begin{array}{c}\text { Panjang } \\
\text { Perjalanan } \\
\text { per hari } \\
\text { (km) }\end{array}$ & $\begin{array}{l}\text { Jarak Tempuh/ } \\
\text { Trip/hari (km) }\end{array}$ & $\begin{array}{c}\text { Jml. Trip } \\
\text { per hari } \\
\text { (km) }\end{array}$ & $\begin{array}{c}\text { Jarak } \\
\text { Perjalanan } \\
\text { Isi per hari } \\
\quad(\mathbf{k m})\end{array}$ & Okupansi (\%) \\
\hline $\mathbf{a}$ & b & c & D & $\mathbf{e}$ & $f=d x e$ & $g=f / c \times 100 \%$ \\
\hline 1 & Blue Bird & 243,585 & 8,27673 & 14,3333 & 118,633 & $46,7291 \%$ \\
\hline 2 & Express & 247,103 & 10,65517 & 12,93103 & 137,782 & $55,8045 \%$ \\
\hline 3 & Matra & 188,610 & 6,898305 & 11,62712 & 80,2074 & $42,6926 \%$ \\
\hline \multicolumn{2}{|c|}{ Rata-rata } & 217,857 & 8,61006833 & 12,9638266 & 112,208 & $48,4087 \%$ \\
\hline
\end{tabular}

Sumber : Purba (2010)

\section{LANDASAN TEORI}

\section{Okupansi}

Okupansi merupakan perbandingan prosentase antara panjang perjalanan taksi isi penumpang dengan total panjang taksi berpenumpang maupun taksi kosong (Tamin, 1997). Rumus untuk menghitung tingkat okupansi adalah :

$$
L F=\frac{\text { JarakPerjalananIsiPenumpang }}{\text { PanjangPerjalananPerHari }} \times 100 \%
$$

Menurut Peraturan Direktur Jenderal Perhubungan Darat Nomor : SK.1905/KP.801/DRJD/2010 Tentang Petunjuk Pelaksanaan Kegiatan Penghargaan Wahana Tata Nugraha, hubungan tingkat okupansi suatu angkutan terhadap kondisi pelayanan angkutan seperti tabel berikut.
Tabel 1. Hubungan Tingkat Okupansi

Terhadap Kondisi Pelayanan Angkutan.

\begin{tabular}{lc}
\hline $\begin{array}{c}\text { Tingkat Okupansi } \\
(\mathbf{\%})\end{array}$ & Kondisi Pelayanan \\
\hline 100 & Sangat baik \\
80 & Baik \\
60 & Sedang \\
40 & Kurang \\
20 & Sangat kurang \\
0 & Tidak ada \\
\hline (Sumber $:$ Direktur & Jenderal Perhubungan Darat, \\
$2010)$ &
\end{tabular}

\section{Biaya Operasi Kendaraan}

Komponen Biaya Operasi Kendaraan terbagi menjadi tiga kelompok utama (Direktorat Jenderal Perhubungan Darat, 2002).

\section{A. Biaya Tetap (Fixed Cost)}

Yaitu biaya yang tidak berubah (tetap) walaupun terjadi perubahan pada produksi jasa sampai ketingkat tertentu. Berikut merupakan komponen dari biaya tetap. 
1. Biaya Penyusutan

Biaya penyusutan merupakan biaya yang dikeluarkan untuk penyusutan nilai kendaraan karena berkurangnya umur ekonomis. Biaya penyusutan dapat dihitung dengan rumus.

Biaya Penyusutan $=$

$H$ arg aKendaraan - Nilai Re sidu

KmTempuhPerTahun $\times$ MasaSusut

Dengan residu $20 \%$ dari harga kendaraan

2. Biaya Bunga Modal

Para pengusaha angkutan antar kota dalam propinsi sebagian besar memilih sistem pemilikan kendaraan dalam sistem kredit beserta bunga yang harus dilunasi dalam jangka waktu tertentu. Pembayaran kredit ini dilakukan dengan cara membayar dengan jumlah tertentu dan tetap setiap tahun, yang terdiri dari pembayaran kembali baik bunga maupun pinjaman pokok sekaligus. Untuk menghitung pembayaran kembali biaya modal kendaraan digunakan rumus.

Biaya Bunga Modal =

$$
\frac{\frac{n+1}{2} x H \text { arg aKendaraan } x \text { TingkatBu nga / Tahun }}{\text { MasaPenyusu } \tan }
$$

Keterangan :

$\mathrm{n}=$ masa pinjaman (tahun)

3. Biaya Pajak Kendaraan Bermotor (STNK)

Perpanjangan STNK dilakukan setiap 5 tahun sekali, tetapi pembayaran pajak kendaraan dilakukan setiap tahun dan biayanya sesuai dengan peraturan yang berlaku.

Biaya STNK $=\frac{0,5 H K}{P S T}$

Keterangan :

HK = Harga Kendaraan

PST $=$ Per seat tahun $/ \mathrm{km}$ tempuh

4. Biaya Kir Bus

Kir kendaraan dilakukan minimal sekali setiap enam bulan dan biayanya sesuai dengan peraturan yang berlaku.

Biaya Kir Bus =

BiayaKirPerTahunPerUnit

$$
\text { PST }
$$

Keterangan :

PST $=$ Per seat tahun $/ \mathrm{km}$ tempuh

5. Biaya Asuransi Kendaraan

Asuransi kendaraan pada umumnya hanya dilakukan oleh perusahaan yang membeli kendaraan secara kredit bank. Namun, asuransi kendaraan perlu diperhitungan sebagai pengamanan dalam menghadapi resiko.

Biaya Asuransi Kendaraan $=\frac{(25 \% \times H K)}{P S T}$

Keterangan :

HK = Harga Kendaraan

PST $=$ Per seat tahun $/ \mathrm{km}$ tempuh

6. Biaya Suku Cadang

Biaya suku cadang adalah biaya yang dikeluarkan untuk pergantian suku cadang dihitung berdasarkan jarak tempuh kendaraan dalam kilometer, walaupun ada yang dengan menghitung bulan.

\section{B. Biaya Tidak Tetap (Variable Cost)}

Biaya tidak tetap merupakan biaya yang dikeluarkan pada saat kendaraan beroperasi. Komponen biaya yang termasuk ke dalam biaya tidak tetap yaitu:

1. Biaya Awak Bus Berikut merupakan biaya awak bus.

a. Susunan awak kendaraan (Supir dan kondektur).

b. Gaji dan tunjangan.

Biaya Awak Bus $=\frac{\text { BiayaAwakPerTahun }}{\text { PST }}$

Keterangan :

PST $=$ Per seat tahun $/ \mathrm{km}$ tempuh

2. Biaya Bahan Bakar minyak (BBM)

Penggunaan Bahan Bakar Minyak secara umum tergantung dari jenis kendaraan dan kapasitas kendaraan. Biaya tersebut diperoleh dari:

Biaya BBM =

BiayaBBMPerBusPerHari

$$
\text { PST }
$$

Keterangan :

PST $=$ Per seat tahun $/ \mathrm{km}$ tempuh

3. Biaya Ban

Biaya ban adalah biaya untuk membeli ban baru atau biaya vulkanisir jika ban masih dalam kondisi layak. Umur layan ban dipengaruhi oleh beban yang dibawa, posisi pada kendaraan, sifat pengemudi dan kondisi jalan (Tamin, 2008).

Biaya Ban =

$\frac{(\text { BiayaBanPerBus })}{(\text { DayaTahanBan }) x(\text { KapasitasAngkut })}$


4. Biaya Pemeliharaan Kendaraan

Biaya yang dikeluarkan untuk pemeliharaan dan perbaikan kendaraan. Biaya perawatan dipengaruhi oleh ciri jalan, terutama kondisi permukaan jalan (Tamin, 2008).

5. Biaya Retribusi Terminal

Biaya retribusi terminal per unit diperhitungkan per hari atau per bulan. Biaya Retribusi $=$

(RetribusiPer HariPerBus)

$$
\text { (SeatKmPerHari) }
$$

\section{Biaya Overhead}

Biaya overhead dapat diketahui melalui 2 cara.

a. Menghitung 20-25\% dari jumlah biaya tetap dan biaya tidak tetap

b. Menghitung biaya overhead secara terperinci yaitu menghitung biaya overhead yang perlu terus dipantau secara berkala oleh pemilik kendaraan.

Biaya Overhead $=$

(Biaya Tetap + Biaya Tidak Tetap) x (20$25 \%)$

\section{HASIL PENELITIAN DAN PEMBAHASAN}

\section{Operator Taksi}

Tabel 2. Karakteristik Operator Taksi

\begin{tabular}{clccc}
\hline No & \multicolumn{1}{c}{ Operator } & Jumlah Sopir & $\begin{array}{c}\text { Jumlah Pegawai } \\
\text { Non Sopir }\end{array}$ & $\begin{array}{c}\text { Jam Operasi } \\
\text { Taksi }\end{array}$ \\
\hline 1 & Koperasi Serba Usaha Pataga & 128 & 16 & 24 jam \\
2 & Koperasi Kokasindo & 65 & 13 & 24 jam \\
3 & Koperasi Tambayo & 65 & 13 & 24 jam \\
4 & PT. Panca Sarana Armada Baru & 70 & 13 & 24 jam \\
5 & Koperasi Primkoppolda DIY & 50 & 15 & 24 jam \\
5 & Primkop Kartika B-1/ Pamungkas & 50 & 15 & 24 jam \\
7 & Koperasi Pandawa & 109 & 11 & 24 jam \\
\hline
\end{tabular}

Berdasarkan hasil survei dan wawancara terhadap beberapa perusahaan taksi, diperoleh rata-rata seluruh jam operasi taksi 24 jam, sebagian penusahaan memiliki jumlah sopir lebih dari 100 sopir, namun demikian masih ada beberapa perusahaan taksi yang kekurangan jumlah sopir, hal ini dikarenakan jumlah armada yang kurang

\section{METDOLOGI PENELITIAN}

\section{Lokasi Penelitian}

Lokasi penelitian yang digunakan untuk pengambilan data adalah pada perusahaanperusahaan taksi yang berada di Daerah Istimewa Yogyakarta tepatnya di kota Yogyakarta, Kabupaten Bantul dan Kabupaten Sleman.

\section{Metode Penelitian}

1. Metode yang digunakan penulis dalam pelaksanaan penelitian ini dengan pengambilan data pada perusahaan taksi yang ada di DIY.

2. Wawancara kepada pimpinan perusahaan taksi yang ada di DIY.

3. Data selanjutnya diolah dan ditampilkan secara deskriptif dan dianalisis. 


\section{Armada Taksi}

Tabel 3. Jumlah Armada Taksi

\begin{tabular}{|c|c|c|c|c|}
\hline \multirow{2}{*}{ No } & \multirow{2}{*}{ Operator } & \multicolumn{3}{|c|}{ Jumlah dan Jenis Kendaraan } \\
\hline & & Sedan (bh) & Mini Bus (bh) & Lainnya (bh) \\
\hline 1 & Koperasi Serba Usaha Pataga & 59 & - & - \\
\hline 2 & Koperasi Kokasindo & 17 & 8 & \\
\hline 3 & Koperasi Tambayo & 17 & 8 & \\
\hline 4 & PT. Panca Sarana Armada Baru & 17 & 8 & \\
\hline 5 & Koperasi Primkoppolda DIY & 32 & - & - \\
\hline 6 & Primkop Kartika B-1/ Pamungkas & 33 & - & - \\
\hline 7 & Koperasi Pandawa & 25 & 32 & - \\
\hline
\end{tabular}

\section{Trip Taksi}

Trip taksi adalah total perjalanan taksi yang beroperasi dalam mengangkut penumpang dalam satu hari. Berikut merupakan jumlah rata-rata trip/hari dari taksi yang beroperasi dalam satu bulan.
Berdasarkan wawancara bahwa sebagian besar trip kebanyakan mengantarkan penumpang yang berasal dari stasiun dan bandara, sehingga banyak armada-armada taksi yang mangkal pada sekitaran daerah tersebut. Peningkatan jumlah trip juga terjadi pada hari sabtu dan minggu atau hari-hari libur lainnya.

Tabel 4. Rata-rata Trip Taksi/Hari

\begin{tabular}{clcc}
\hline No. & Perusahaan Taksi & Rata-rata Kendaraan/Hari & Rata-rata Trip/Hari \\
\hline 1 & Koperasi Pandawa & 48,67 & 24 \\
2 & Koperasi Usaha Pataga & 32,33 & 14 \\
3 & Primkoppolda DIY & 24,63 & 18 \\
4 & Primkop Kartika B-1/Pamungkas & 24,57 & 19 \\
5 & PT. Panca Sarana Armada Baru & 21,33 & 14 \\
6 & Koperasi Kokasindo & 19,87 & 15 \\
7 & Koperasi Tambayo & 21,77 & 15 \\
\hline
\end{tabular}

\section{Tingkat Okupansi}

Tabel. 5. Tingkat Okupansi Taksi DIY

\begin{tabular}{|c|c|c|c|c|c|c|}
\hline No & Operator & $\begin{array}{c}\text { Panjang } \\
\text { Perjalanan } \\
\text { Per Hari } \\
\text { (km) }\end{array}$ & $\begin{array}{c}\text { Jarak } \\
\text { Tempuh } \\
\text { Per } \\
\text { Trip/Hari } \\
\text { (km) }\end{array}$ & $\begin{array}{l}\text { Jumlah } \\
\text { Trip } \\
\text { Per } \\
\text { Hari } \\
\text { (kali) }\end{array}$ & $\begin{array}{c}\text { Jarak } \\
\text { Perjalanan } \\
\text { Isi Per } \\
\text { Hari (km) }\end{array}$ & $\begin{array}{c}\text { Okupansi } \\
(\%)\end{array}$ \\
\hline $\mathbf{a}$ & b & c & d & e & $f=d \times e$ & $\begin{array}{c}g=f / c x \\
100 \%\end{array}$ \\
\hline 1 & Koperasi Pandawa & 256,98 & 4,36 & 24,10 & 105,17 & $41 \%$ \\
\hline 2 & Koperasi Serba Usaha Pataga & 181,28 & 4,87 & 13,87 & 67,53 & $37 \%$ \\
\hline 3 & Koperasi Primkoppolda DIY & 217,52 & 4,27 & 18,43 & 78,80 & $36 \%$ \\
\hline 4 & Primkop Kartika B-1/Pamungkas & 217,30 & 4,29 & 18,77 & 80,44 & $37 \%$ \\
\hline 5 & PT. Panca Sarana Armada Baru & 244,00 & 4,52 & 14,47 & 65,39 & $27 \%$ \\
\hline 6 & Koperasi Kokasindo & 206,85 & 3,4 & 14,67 & 49,87 & $24 \%$ \\
\hline \multirow[t]{2}{*}{7} & Koperasi Tambayo & 188,45 & 3,26 & 14,67 & 47,81 & $25 \%$ \\
\hline & Rata-rata & 216,06 & 4,14 & 17,00 & 70,72 & $33 \%$ \\
\hline
\end{tabular}


Hasil perhitungan tingkat okupansi memperlihatkan diantara tujuh perusahaan taksi seperti pada tabel diatas. Berdasarkan acuan penilaian Standar Direktur Jenderal Perhubungan Darat tentang Hubungan Tingkat Okupansi Terhadap Kondisi Pelayanan Angkutan bahwa dari sebagian perusahaan taksi pada penelitian ini memiliki rata-rata tingkat okupansi sebesar $33 \%$ yang berarti pelayanan taksi masih kurang baik.

\section{Biaya Operasional Kendaraan (BOK)}

Pada perhitungan BOK yang ditampilkan berupa sampel perhitungan BOK salah satu perusahaan taksi di Yogyakarta yaitu perusahaan Primkoppolda DIY, untuk detail perhitungan BOK perusahaan lainnya akan dicantumkan pada daftar lampiran.

\section{Biaya Tetap (Fixed Cost)}

Biaya tetap merupakan biaya yang tidak berubah (tetap) walaupun terjadi penbahan pada produksi jasa sampai ketingkat tertentu.

a. Biaya Penyusutan

Perhitungan biaya penyusutan dengan nilai residu sebesar $20 \%$ dan masa susut selama lima tahun. Perhitungan biaya penyusutan digunakan rumus :

\section{$\frac{H \text { arg aKendaraan }- \text { Nilai Re sidu }}{\text { KmTempuhPerTahun } \times \text { MasaSusut }}$}

Berikut merupakan salah satu contoh biaya penyusutan dari perusahaan Primkoppolda DIY.

Tabel 6. Biaya Penyusutan

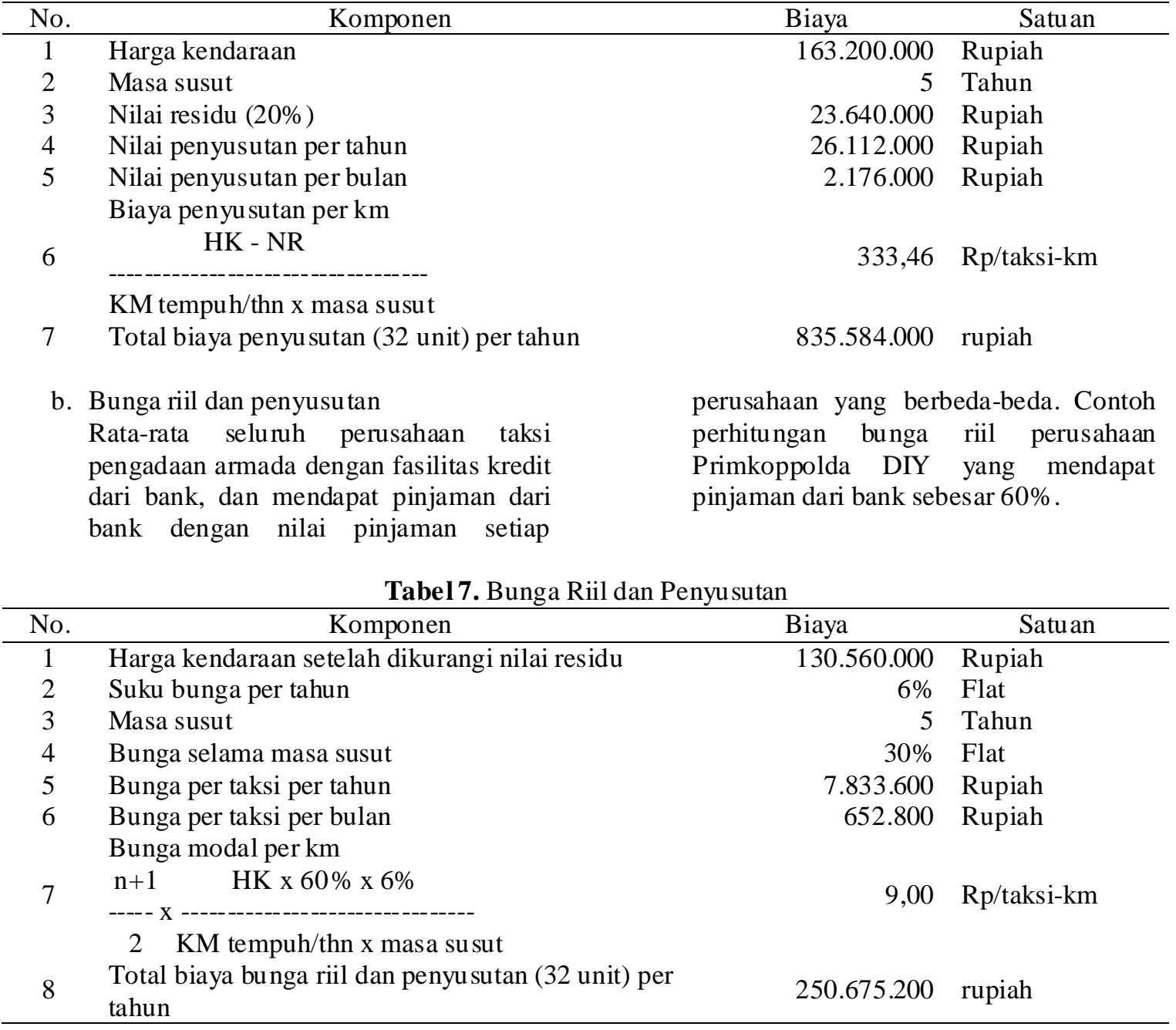


c. Biaya PKB

Berdasarkan hasil wawancara untuk biaya Pajak Kendaraan Bermotor angkutan taksi sebagian besar mendapatkan keringanan berupa diskon sebesar $30 \%-50 \%$.

Biaya PKB 1 unit Hyundai Excell =

Rp. $542.000,-=$ Rp. 6,92,-/km

Harga PKB untuk seluruh unit taksi diasumsikan sama

Biaya PKB (32 unit)= Rp. 542.000,- x 32

= Rp. 17.344.000,-

d. Asuransi Pengemudi

Pengemudi angkutan taksi diauransikan sebesar Rp.150.000,- per tahun.

Biaya asuransi pengemudi per tahun

$=$ Rp. 150.000,-

$=$ Rp. 22,99, $-/ \mathrm{km}$

Biaya asuransi (50 pengemudi) per tahun

$=$ Rp. $150.000,-\mathrm{x} 50$

$=$ Rp. 7.500.000,-

e. Asuransi Kendaraan

Asuransi kendaraan pada perusahaan taksi berupa Total Lost Only (TLO) yang berarti ganti rugi oleh perusahaan asuransi jika mobil mengalami kenusakan total atau diatas $75 \%$. Nilai asuransi sebesar 0,8\% dari harga kendaraan. Pada perusahaan Primkoppolda DIY dengan mobil seharga Rp.163.200.000,- maka asuransi sebesar $0,8 \% \quad \mathrm{x}$ Rp.163.200.000,- = Rp. 1.305.600,Harga kendaraan $=$ Rp. 163.200.000,Biaya asuransi $=0,8 \% \mathrm{x}$ Rp.163.200.000,- = Rp. 1.305.600,- = Rp. $16,67, / \mathrm{km}$

Biaya asuransi (32 unit) $=$ Rp. 1.305.600 x 32 = Rp. 41.779.200,-

f. Biaya Keur

Biaya keur dilakukan setiap enam bulan sekali yang berarti dua kali dalam setahun. Untuk biaya angkutan taksi memiliki tarif biaya keur yang berbeda sesuai dengan daerah perusahaan berada. Perusahaan taksi yang berada di sekitar Kota Yogyakarta berdasarkan Perda Yogyakarta No.17 tahun 2009 dikenakan biaya keur sebesar Rp.65.000 per sekali keur. Penusahaan yang berada di Kabupaten Sleman berdasarkan Perda Sleman No.3 Tahun 2012 dikenakan biaya sebesar Rp.65.000, dan untuk perusahaan yang berada di Kabupaten
Bantul berdasarkan Perda No.9 tahun 2011 dikenakan biaya sebesar Rp.58.500. Biaya per sekali keur= Rp. 65.000,(Kab.Sleman)

Biaya keur per tahun (2 kali keur) $=$ Rp.65.000,- x 2= Rp. 130.000,- = Rp. 1,66,/km

Biaya keur per tahun (32 unit) $=$ Rp. 130.000,- x 32 = Rp. 2.160.000,-

g. Asuransi Penumpang Biaya asuransi penumpang dikenakan sebesar Rp.180.000 per bulan.

Biaya asuransi penumpang per tahun $=$ Rp. $180.000 \times 12=$ Rp. 2.160.000,-

$=$ Rp. $27,58, / \mathrm{km}$

h. Iuran Anggota Organda

Iuran anggota organda setiap perusahaan dikenakan biaya sebesar Rp.4000 per bulan/taksi.

Biaya iuran organda per tahun = Rp. 4.000,- x 12 = Rp. 48.000,-

Biaya iuran organda (32 unit) per tahun = Rp. 48.000,- x 32 = Rp. 1.536.000,-

i. Biaya Ijin Frekuensi

Biaya ijin frekuensi dikenakan biaya sebesar Rp.36.000 per bulan.

Biaya ijin frekuensi per tahun $=$ Rp. 36.000 ,- x $12=$ Rp. $432.000,-=$ Rp. 5,52,$/ \mathrm{km}$

j. Biaya Pegawai

Biaya pegawai dikeluarkan oleh perusahaan setiap sebulan sekali. Berdasarkan hasil wawancara untuk biaya pegawai mengikuti per bulan nya mengikuti UMP.

k. Biaya Tunjangan

Biaya tunjangan diberikan perusahaan baik kepada pegawai sopir maupun pegawai non sopir. Untuk pegawai sopir biasanya perusahaan menyediakan bingkisan dan juga sembako dengan jumlah biaya yang berbeda-beda per perusahaan.

1. Biaya PBB

Biaya PBB dilakukan setiap satu tahun sekali oleh penusahaan taksi.

m. Biaya Seragam

Setiap perusahaan memberikan seragam kepada pengemudi taksi dengan agar penumpang lebih merasa nyaman karena dengan memakai seragam maka identitas dari pengemudi akan terlihat. Untuk biaya seragam setiap perusahaan mengeluarkan biaya yang berbeda, 
contohnya seperti perusahaan Primkoppolda DIY mengeluarkan biaya Rp.80.000 per orang.

Biaya per tahun (50 pengemudi) =

Rp. $80.000,-$ x $50=$ Rp. $4.000 .000,-=$ Rp. 1,02,-

\section{Biaya Tidak Tetap (Variable Cost)}

a. Biaya BBM

Biaya BBM angkutan taksi lebih dibebankan kepada pengemudi taksi dimana pengemudi taksi yang menanggung biaya BBM pada saat taksi beroperasi dan perusahaan hanya menanggung BBM pada saat sebelum taksi beroperasi yaitu dengan mengisi BBM full sesuai dengan kapasitas tangki bensin dan taksi kembali setelah beroperasi dalam keadaan BBM yang full kembali. Berikut contoh perhitungan BBM salah satu perusahaan yaitu Primkoppolda DIY.

Tabel 8. Biaya BBM

\begin{tabular}{clrl}
\hline No. & \multicolumn{1}{c}{ Komponen } & Biaya & \multicolumn{1}{c}{ Satuan } \\
\hline 1 & Kapasitas tangki & 45 & Liter \\
2 & Perbandingan 1 liter bensin dengan jarak tempuh & 1 liter : $11 \mathrm{~km}$ & \\
3 & Harga BBM per liter & 7.400 & Rupiah \\
4 & Harga BBM full tangki & 333.000 & Rupiah \\
5 & Harga BBM full tangki (32 unit) & 10.656 .000 & Rupiah \\
6 & Jarak tempuh satu kali isi full & 495 & $\mathrm{~km}$ \\
7 & Biaya BBM/taksi-km & 672,73 & Rp/taksi-km \\
\hline
\end{tabular}

b. Biaya Ban

Biaya ban merupakan biaya untuk membeli ban baru atau biaya vulkanisir jika ban masih dalam kondisi layak. Pada perhitungan ini pergantian ban disesuaikan dengan daya tahan ban dan jarak taksi yang ditempuh dalam satu tahun. Berikut contoh perhitungan baiya ban.

Tabel 9. Biaya Ban

\begin{tabular}{clrl}
\hline No. & \multicolumn{1}{c}{ Komponen } & Biaya & \multicolumn{1}{c}{ Satuan } \\
\hline 1 & Penggunaan ban per taksi & 4 & buah \\
2 & Pergantian ban per tahun & 2 & kali \\
3 & Daya tahan ban & 45000 & km \\
4 & Harga ban per buah & 688.000 & Rupiah \\
5 & Biaya ban per taksi & 2.752 .000 & Rupiah \\
6 & Biaya ban per tahun per taksi (2 kali ganti) & 4.788 .920 & rupiah \\
7 & Biaya ban (32 unit taksi) & 153.245 .450 & rupiah \\
8 & Biaya ban/taksi-km & 35,14 & Rp/taksi-km \\
\hline
\end{tabular}

c. Biaya Pemeliharaan Kendaraan

1) Service Kecil

Tabel 10. Rincian Kebutuhan Service Kecil

\begin{tabular}{clcc}
\hline No. & Item & Kebutuhan & Biaya \\
\hline 1 & Oli mesin & 4 liter & 146.000 \\
2 & Gemuk & $0,5 \mathrm{~kg}$ & 13.750 \\
\hline \multicolumn{3}{c}{ Ongkos kerja (Rp.) } \\
\hline \multicolumn{3}{c}{ Total Biaya (Rp.) } & 100.000 \\
\hline \multicolumn{5}{c}{} & 259.750
\end{tabular}

Tabel diatas merupakan contoh perhitungan biaya service kecil pada perusahaan Primkoppolda DIY Jarak tempuh satu kali service $=7500$ $\mathrm{km}$
Waktu service per tahun = $78.307 / 7500=10$ kali Biaya perawatan service kecil $=$ Rp. 259.750,- x 10 kali = Rp. $2.597 .500,-=$ Rp. $34,63,-/ \mathrm{km}$ 
Biaya service kecil 32 unit (10 kali

$=$ Rp. 83.120.000,-

service) $\quad=$ Rp.2.597.500,- $\mathrm{x} 32$

2) Service Besar

Tabel 11. Rincian Kebutuhan Service Besar

\begin{tabular}{clcc}
\hline No. & \multicolumn{1}{c}{ Item } & Kebutuhan & Biaya \\
\hline 1 & Oli mesin & 4 liter & 146.000 \\
2 & Gemuk & $0,5 \mathrm{~kg}$ & 13.750 \\
3 & Oli gardan & 1 liter & 31.000 \\
4 & Oli transmisi & 2 liter & 75.000 \\
5 & Minyak rem & 0,5 liter & 16.500 \\
6 & Filter oli & 1 buah & 30.000 \\
7 & Filter udara & 1 buah & 175.000 \\
8 & Air aki & 2 botol & 11.000 \\
\hline \multicolumn{2}{c}{ Ongkos kerja (Rp.) } \\
\hline \multicolumn{2}{c}{ Total Biaya (Rp.) } & 200.000 \\
\hline
\end{tabular}

Jarak tempuh satu kali service $=30.000 \mathrm{~km}$

Waktu service per tahun $=78.307 /$ $30.000=3$ kali

Biaya perawatan service kecil $=$ Rp.698.250,- $\quad$ x 3 kali = Rp.2.049 250,- = Rp. 23,28,-/km Biaya service kecil 32 unit (3 kali service) $\quad=$ Rp.2.049.250,- $\mathrm{x} 32$

$=$ Rp. 67.032.000,-
3) Biaya Cuci Taksi

Biaya cuci taksi per hari $=$ Rp. $15.000,-=$ Rp. $68,96, / \mathrm{km}$ Biaya cuci taksi per tahun = Rp. 15.000,- x 360 = Rp. 5.400.000,-

4) Biaya Tera Argometer

Biaya tera argometer satu tahun per taksi $=$ Rp. 50.000,- = Rp. 0,6,-

Biaya tera argometer satu tahun (32 unit) = Rp. 50.000,- $\times 32=$ Rp. 1.600.000,-

Tabel 12. Rekap Hasil Perhitungan BOK

\begin{tabular}{lcccc}
\hline \multicolumn{1}{c}{ Perusahaan } & $\begin{array}{c}\text { Total } \\
\text { Jumlah } \\
\text { Armada }\end{array}$ & $\begin{array}{c}\text { Biaya Tetap } \\
\text { (Rp.) }\end{array}$ & $\begin{array}{c}\text { Biaya Tidak Tetap } \\
\text { (Rp.) }\end{array}$ & $\begin{array}{c}\text { BOK } \\
\text { (Rp.) }\end{array}$ \\
\hline Koperasi Usaha Pataga & 59 & 3.116 .201 .339 & 838.637 .543 & 3.954 .838 .882 \\
Koperasi Pandawa & 57 & 2.945 .431 .017 & 971.184 .634 & 3.916 .615 .651 \\
Koperasi Kokasindo & 25 & 1.253 .033 .850 & 467.152 .947 & 1.720 .186 .797 \\
PT. Panca Sarana Armada & 25 & 1.427 .493 .010 & 477.968 .646 & 1.905 .461 .656 \\
Baru & 25 & 1.268 .564 .450 & 447.861 .670 & 1.716 .426 .120 \\
Koperasi Tambayo & 33 & 1.470 .162 .100 & 589.697 .987 & 2.059 .860 .087 \\
Primkop Kartika B- & 32 & 1.419 .118 .900 & 577.646 .150 & 1.996 .765 .050 \\
1/Pamungkas & & & & \\
Primkoppolda DIY & & &
\end{tabular}




\section{KESIMPULAN DAN SARAN}

\section{Kesimpulan}

1. Dari ke-7 perusahaan diatas di dapat ratarata tingkat okupansi sebesar 33\%. Menurut Peraturan Direktorat Jenderal Perhubungan Darat SK.1905/KP.801/DRJD/2010 Tentang Hubungan Tingkat Okupansi Suatu Angkutan Terhadap Kondisi Pelayanan Angkutan bahwa tingkat okupansi taksi di DIY masih sangat kurang sehingga pelayanan taksi di DIY perlu lebih ditingkatkan.

2. Pada perhitungan Biaya Operasional Kendaraan (BOK) 7 penusahaan di DIY Koperasi Serba Usaha Pataga dengan total BOK sebesar Rp.3.954.838.882,- dan selanjutnya adalah Koperasi Pandawa sebesar Rp.3.916.615.651,- $\quad$ Primkoppol Kartika B-1/Pamungkas sebesar Rp.2.059.860.087,- $\quad$ Primkoppolda DIY sebesar Rp.1.996.765.050,- PT. Panca Sarana Armada Baru sebesar Rp.1.905.461.656, Koperasi Kokasindo sebesar Rp.1.720.186.797,-- dan Koperasi Tambayo sebesar Rp.1.716.426.120.-

\section{Saran}

1. Dilihat dari tingkat okupansi yang masih kurang pada 7 perusahaan taksi yang ada di DIY, perlu adanya peningkatan pelayanan taksi di DIY. Salah satu upaya dalam penungkatan pelayanan dengan memanfaatkan teknologi Internet seperti Google Maps, Ruby on Rails yang dikombinasikan dengan perangkat bergerak berbasis Android.

2. Perlunya pengawasan dan tindak lanjut terhadap taksi gelap yang beroperasi. Dikarenakan taksi uber merupakan taksi yang tidak memiliki ijin dari dinas perhubungan untuk beroperasi. Selain itu, taksi uber juga secara tidak langsung merugikan pengemudi taksi resmi karena mengambil penumpang yang seharusnya bukan milik taksi tersebut.

\section{DAFTAR PUSTAKA}

Dinas Perhubungan Komunikasi dan Informatika Daerah Istimewa Yogyakarta, 2014

Keputusan Direktur Jenderal Perhubungan Darat Nomor : SK.687/AJ.206/DRJD/2002 tentang Pedoman Teknis Penyelenggaraan Angkutan Penumpang Umum Di Wilayah Perkotaan Dalam Trayek Tetap Dan Teratur

Kurniati, T., 2007., “Tinjauan Penetapan Tarif Taksi Di Kota Padang”., ISSN: 854-8471, No. 27 Vol.3 Thn. XIV April 2007, Universitas Andalas.

Peraturan Daerah Kabupaten Bantul Nomor 9 Tahun 2011 tentang Retribusi Jasa Umum

Peraturan Daerah Kabupaten Sleman Nomor 3 Tahun 2012 tentang Retribusi Pengujian Kendaraan Bermotor

Peraturan Direktur Jenderal Perhubungan Darat Nomor SK.1905/KP.801/DRJD/2010 tentang Petunjuk Pelaksanaan Kegiatan Penghargaan Wahana Tata Nugraha, Hubungan Tingkat Okupansi Suatu Angkutan Terhadap Kondisi Pelayanan Angkutan

Purba, G.C., Yusandy, A.2010., “Analisa Supply Dan Demand Angkutan Taksi Di Kota Medan Berdasarkan Tingkat Okupansi Dan Biaya Operasional Kendaraan”, Universitas Sumatera Utara.

Republik Indonesia, 2014, Peraturan Pemerintah Nomor 74 Tahun 2014 tentang Angkutan Jalan

Sriwidodo, 2005,. “Analisis Keseimbang Supply-Demand Angkutan Taksi Dikota Semarang”, Tesis, Universitas Diponegoro.

Tamin, O.Z., 1997, Perencanaan Dan Permodelan Transportasi, Penerbit ITB, Bandung

Tamin, O.Z., 2008, Perencanaan, Permodelan Dan Rekayasa Transportasi, Penerbit ITB, Bandung. 